Original Article

\title{
Praktik Menyusui pada Anak Baduta Berat Badan Kurang
}

\section{Breastfeeding Practices in Baduta of Underweight.}

\author{
Dwi Erma Kusumawati* \\ Poltekkes Kemenkes Palu, Indonesia \\ (dwiekw@gmail.com. 08124200043)
}

\begin{abstract}
ABSTRAK
Masalah anak kekurangan gizi di Indonesia belum sepenuhnya teratasi. kejadian gizi kurang (underweight) merupakan manisfestasi dari kekurangan asupan gizi yang jika berlangsung dalam waktu lama maka akan berkontribusi terhadap kejadian stunting dikemudian hari. Penelitian ini bertujuan menggambarkan praktik menyusui pada anak baduta status gizi kurang. Desain penelitian deskriptif untuk menggambarkan praktik menyusui ibu baduta dengan kejadian berat badan kurang. Populasi dan besar sampel adalah 34 anak baduta dengan status gizi berat badan kurang dengan purposive sampling, Pelaksanaannya pada bulan desember 2021 dan berlokasi di wilayah kerja puskesmas Mamboro kecamatan palu utara. Analisis data univariat dan penyajian data menggunakan tabel dan narasi. Hasil penelitian menunjukkan pendidikan ibu sebagain besar SMA/Sederajat $(64,7 \%)$. Pekerjaan Ibu di dominasi sebagai URT sebesar $94,1 \%$, Sebagain besar ibu status paritasnya multipara 79,4\%. Panjang Badan Lahir di bawah angka median 49,9 cm menurut indeks PB/U sebesar 64,7\%. Ada 13 orang ibu $(38,2 \%)$ yang saat melahirkan bayinya tidak dilakukan Inisiasi menyusui Dini (IMD). Sebanyak 18 orang ibu $(52,9 \%)$ tidak memberikan ASI Ekslusif dengan masalah menyusui karena merasa asinya sedikit $(17,6 \%)$. Ada 18 orang ibu (52,9\%) yang konsultasikan masalah selama menyusui ke petugas kesehatan. Terdapat 25 orang ibu $(73,5 \%)$ yang memberikan botol susu dengan usia pemberian dibawah 6 bulan sebesar 76\%. Terdapat praktik menyusui pada bayi dan anak baduta yang tidak sesuai. Dibutuhkan penangnanan melibatkan multifactor.
\end{abstract}

Kata kunci : Praktik Menyusui, Baduta, Berat Badan Kurang.

ABSTRACT
The problem of child malnutrition in Indonesia is not yet fully resolved. Underweight are manifestations of the deficiency of nutrient intake that is if it lasts for a long time then it will contribute to the incidence of stunting in the future. This study aims to describe the practice of breastfeeding in baduta with the status of malnutrition. Descriptive research design to describe the practice of breastfeeding mothers baduta with the Underweight. Population and amount of the sample is 34 baduta with the nutritional status of Underweight with purposive sampling technique, the Implementation is in December 2021 and is located in the working area of puskesmas Mamboro kecamatan palu utara. Data analysis is univariate and the presentation of data using tables and narrative. The results showed that maternal education, mostly high School (64,7\%). Mother's work in dominance as the URT of $94.1 \%$ are, Most of the mother's status Paritas Multipara of $79.4 \%$. Low birth length in the median of $49.9 \mathrm{~cm}$ according to the $\mathrm{PB} / \mathrm{U}(8)$ for $64.7 \%$. There are 13 mothers (the $38.2 \%$ ) who gave birth to her baby is not done Early Initiation of breastfeeding (IMD). There are 18 mother (52,9\%) did not give Exclusive breastfeeding with breastfeeding problems because they think they have small amount of breastmilk $(17,6 \%)$. There are 18 mother $(52,9 \%)$ who consult any problems during breastfeeding to the health officer. There are 25 mother $(73.5 \%)$ that gives a bottle of milk with the age of the provision under 6 months amounted to $76 \%$. There are practices of breastfeeding in infants and baduta that do not fit. It needs handlings that involves multifactor.

Keywords : The practice of breastfeeding, Under 2 years old Underweight. 


\section{PENDAHULUAN}

Masalah anak kekurangan gizi di Indonesia belum sepenuhnya teratasi. Menurut data Riskesdas 2018 dan Survei Studi Status Gizi Indonesia (SSGI) 2019 dan 2021, prevalensi Stunting masih sebesar 30,8\% ditahun 2018. Angka ini turun di tahun 2019 dna 2020 menjadi masing-masing 27,7\% dan 24,4\% ${ }^{1234}$. Angka kejadian tersebut menunjukkan bahwa masih ada 2-3 dari 10 anak balita menderita stunting di Indonesia. Standar Organisasi Kesehatan Dunia (WHO) untuk kejadian Stunting yaitu maksimal $20 \%$ dari jumlah total anak balita dalam satu negara sehingga jika dilihat angka prevalensi yang terjadi tentu masih diatas angka yang disarankan.

Stunting adalah suatu kondisi dimana seorang anak memiliki tinggi badan yang tidak sesuai dengan usianya yang disebabkan mengalami gangguan pertumbuhan akibat dari masalah gizi kronis yaitu kekurangan asupan gizi dalam waktu yang lama ${ }^{5}$. kejadian gizi kurang (underweight) merupakan manisfestasi dari kekurangan asupan gizi yang jika berlangsung dalam waktu lama maka akan berkontribusi terhadap kejadian stunting dimasa yang akan datang. Menurut data Survei Studi Status Gizi Indonesia (SSGI) 2019 prevalensi Underweight menunjukkan angka sebesar $16,3 \%$, Angka ini memang turun dari prevalensi menurut Riskesdas 2018 yang mencapai 17,7\%, tapi menurut laporan SSGI prevalensinya naik menjadi menjadi sebesar $17 \%$ di tahun $2021^{13}$. Begitu juga prevalensi wasting yang walaupun kejadiannya sudah tidak menjadi suatu katagori yang serius seperti tahun sebelumnya, tapi kejadian ini harus tetap menjadi perhatian. Data UNICEF) pada yahun 2013 menyatakan bahwa wasting menyumbang 60\% kematian anak balita sebagai bawaan terhadap penyakit infeksi mematikan ${ }^{6}$.

Potensi peningkatan kejadian anak yang mengalami kekurangan gizi di Indonesia diprediksikan meningkat di masa pandemic covid 2019 yg di karenakan perekonomian keluarga menurun. Rendahnya pendapatan keluarga dapat mempengaruhi pemenuhan kebutuhan pangan anak. Kemampuan rumah tangga dalam menyediakan makanan utama akan mempengaruhi kesesuaian standar asupan untuk anak, ibu hamil dan ibu menyusui. ${ }^{78}$

Usia baduta merupakan periode emas atau golden age dimana pada usia tersebut merupakan tahapan pertumbuhan dan perkembangan yang paling penting pada masa awal kehidupan anak. Agar kebutuhan gizi pada masa tersebut dapat adekuat, maka berdasarkan rekomendasi WHO menyarankan bahwa ada 4 satandar makan pada bayi dan anak yaitu pemberian IMD. ASI eksklusif, MP-ASI pada usia lebih dari 6 bulan dan meneruskan pemberian ASI sampai anak berusia 2 tahun $^{9}$

Menurut data Survei Studi Status Gizi Indonesia 2021 menggambarkan prevalensi berat badan kurang (underweight) di Sulawesi tengah masih sebesar 23,8\% dengan Kota Palu sebesar $18.0 \%$. Angka ini masih di atas angka kejadian di Indonesia (17\%) ${ }^{2}$.

Penelitian ini bertujuan menggambarkan praktik menyusui pada baduta dengan kejadian status gizi kurang di Wilayah Kerja Puskesmas Mamboro kecamatan Palu Utara Kota Palu.

\section{METODE PENELITIAN}

Penelitian ini menggunakan desain penelitian deskriptif untuk menggambarkan praktik menyusui ibu anak baduta berat badan kurang di wilayah kerja puskesmas mamboro. Populasi adalah anak baduta yang dengan status gizi berat badan kurang. Waktu penelitian padan bulan desember 2021 dengan lokasi penelitian Posyandu diwilayah kerja puskesmas Mamboro yang ada di kecamatan palu utara. Besar sampel adalah total populasi sebanyak 34 ibu yang memiliki baduta berat badan kurang dengan Teknik pengambilan sampel purposive.

Variabel penelitian adalah praktik menyusui yang meliputi IMD, Asi Ekslusif, melanjutkan ASI sampai 2 tahun, masalah/kendala dalam menyusui, peran dan bentuk dukungan pada ibu menyusui serta penggunaan botol susu. Data dikumpulkan dengan wawancara menggunakan kuesioner yang berisikan pertanyaan terbuka lalu disimpulkan dan dikategorikan. Analisis data univariat dan penyajian data menggunakan tabel frekuensi dan narasi.

Kegiatan penelitian yang dilaksanakan selama bulan desember 2021 ini melibatkan enumerator yang sudah dilatih dengan kemampuan sebagai konselor yaitu ketrampilan mendengarkan dan mempelajari. Langkah yang dilakukan sebelum mengambil data pada responden adalah dengan mengumpulkan data baduta yang ada di wilayah kerja puskesmas mamboro yang kemudian dinilai status gizi anak baduta berdasarkan indeks antropometri $\mathrm{BB} / \mathrm{U}$ sehingga di dapatkan jumlah anak yang memiliki status gizi berat badan kurang. Data anak baduta di kumpulkan dari data sekunder 
yang bersumber dari kader posyandu dari hasil penimbangan baduta yang berusia 6 bulan sampai dengan 24 bulan pada bulan November 2021.

\section{HASIL}

Tabel 1 menunjukkan bahwa umur yang menjadi responden dalam penelitian ini hampir seimbang antara yang usianya di bawah 30 tahun dan di atas 30 tahun. Pendidikan ibu sebagain besar SMA/Sederajat sejumlah 22 orang sebesar $64,7 \%$. Pekerjaan Ibu di dominasi sebagai URT (Urusan Rumah Tangga) dengan jumlah 32 orang ibu $(94,1 \%)$. Ada 7 orang ibu yang status paritasnya primipara atau sebesar 20,6\%. Jenis kelamin seimbang antara laki-laki dan perempuan masing- masing berjumlah 17 orang atau sebesar 50\%. Rentang umur anak terbanyak berada pada usia 13 sampai dengan 24 sebesar 23 orang anak $(67,6 \%)$. Berat badan lahir anak hanya 3 orang anak $(8,8 \%)$ yang mempunyai riwayat Berat Badan Lahir Rendah (BBLR) akan tetapi riwayat Panjang Badan Lahir di bawah angka median 49,9 cm menurut indeks $\mathrm{PB} / \mathrm{U}^{10}$ sebanyak 22 orang anak atau sebesar $64,7 \%$.

Tabel. 1. Distribusi Karakteristik Ibu dan Anak Baduta Kejadian Berat Badan Kurang di Wilayah Kerja Puskesma Mamboro.

\begin{tabular}{lll}
\multicolumn{1}{c}{ Karakteristik (n=34) } & n & \% \\
\hline Usia Ibu & & \\
<30 thn. & 18 & 52,9 \\
=>30 thn & 16 & 47,1 \\
Pendidikan Ibu & & \\
Diploma/Sarjana & 2 & 5,9 \\
SMA/Sederajat & 22 & 64,7 \\
SMP/Sederajat & 4 & 11,8 \\
SD/Sederajat \\
$\begin{array}{l}\text { Pekerjaan Ibu } \\
\text { URT }\end{array}$ & 6 & 17,6 \\
Pegawai Honorer & 32 & 94,1 \\
Paritas & 2 & 5,9 \\
Primipara & & \\
Multipara & 7 & 20,6 \\
Jenis Kelamin Anak & 27 & 79,4 \\
Laki-laki & & \\
Perempuan & 17 & 50 \\
Usia Anak & 17 & 50 \\
6-8 bulan & & \\
9-12 bulan & 4 & 11,8 \\
>12 bulan \\
Berat Badan Lahir \\
< 2500 gram
\end{tabular}

Berdasarkan tabel 2 menunjukkan hasil bahwa ada 13 orang ibu $(38,2 \%)$ yang saat melahirkan bayinya tidak dilakukan Inisiasi menyusui Dini (IMD) dengan penyebab terbanyaknya menurut ibu adalah petugas Kesehatan tidak membantu melakukan IMD sebanyak 5 orang (14,7\%). Ada 18 orang ibu $(52,9 \%)$ tidak memberikan ASI Ekslusif dengan alasan terbanyak dikarenakan asinya terlambat keluar sesaat setelah bayi dilahirkan $(11,8 \%)$ dan merasa ASI-nya hanya sedikit sehingga ASI saja tidak cukup memenuhi kebutuhan Bayi $(11,8 \%)$. Ketika masa pemberian ASI Ekslusif, ada 8 orang ibu (44\%) yang melakukan upaya dalam mengatasi masalah menyusui yang muncul pada saat itu. Setelah periode pemberian ASI Ekslusif pada anak, terdapat 15 orang ibu $(44,1 \%)$ yang melanjutkan pemberian ASI disamping pemberian Makanan Pendamping ASI (MPASI). Masalah menyusui yang dialami oleh ibu selama perioden menyusui sampai kontak terakhir dengan responden adalah di dominasi karena merasa asinya sedikit sebesar $17,6 \%$. Adapun yang tidak mengalami masalah dalam menyusui sebanyak 8 orang $(23,5 \%)$ yang di 2 diantaranya karena ibunya tidak pernah menyusui anaknya dari usia anak 0 bulan.

Ada 18 orang ibu $(52,9 \%)$ yang memiliki masalah selama menyusui yang berkonsultasi ke petugas Kesehatan yaitu dokter anak, bidan dan tenaga pelaksana gizi (TPG). Selama periode menyusui anaknya, para ibu banyak mendapatkan dukungan dari suami, orang tua terutama nenek atau ibu sendiri dan mertua, keluarga dan petugas Kesehatan terutama bidan sebanyak 23 orang ibu $(67,6 \%)$ dan ada 3 orang ibu yang merasa tidak mendapatkan dukungan dari lingkungan sekitarnya $(8,8 \%)$.

Dalam penelitian ini juga ditanyakan mengenai penggunaan botol dot susu dalam pemberian cairan pada anak. Ada 25 orang ibu $(73,5 \%)$ yang memberikan dengan media botol dot susu dimana usia diperkenalkan paling banyak pada usia dibawah 6 bulan sebanyak 19 orang atau sebesar $76 \%$

Tabel 2. Distribusi Praktik Menyusui Ibu Anak Baduta Kejadian Berat Badan Kurang di Wilayah Kerja Puskesma Mamboro.

\begin{tabular}{lcc}
\hline \multicolumn{1}{c}{ Variabel } & n & \% \\
\hline IMD $(\mathbf{n}=\mathbf{3 4})$ & & \\
Ya & 21 & 61,8 \\
Tidak & 13 & 38,2 \\
Alasan Tidak IMD $(\mathbf{n}=\mathbf{1 3})$ & & \\
Operasi Cesar & 3 & 8,8 \\
Kondisi Ibu Lemas & 1 & 2,9 \\
\hline
\end{tabular}




\begin{tabular}{|c|c|c|}
\hline Variabel & $\mathbf{n}$ & $\%$ \\
\hline Pendarahan pasca melahirkan & 2 & 5,9 \\
\hline Bayi lahir dengan masalah & 2 & 5,9 \\
\hline Petugas Kesehatan Tidak dilakukan IMD & 5 & 14,7 \\
\hline \multicolumn{3}{|l|}{ Asi Ekslusif $(n=34)$} \\
\hline Ya & 16 & 47,1 \\
\hline Tidak & 18 & 52,9 \\
\hline \multicolumn{3}{|l|}{ Alasan Tidak Asi ekslusif $(n=18)$} \\
\hline Asi terlambat keluar & 4 & 11,8 \\
\hline Asi sedikit keluar & 4 & 11,8 \\
\hline Asi saja tidak cukup & 1 & 2,9 \\
\hline Puting terbenam & 3 & 8,8 \\
\hline Asi tidak keluar & 1 & 2,9 \\
\hline Komplikasi medis & 1 & 2,9 \\
\hline Payudara bengkak & 1 & 2,9 \\
\hline Anak menolak menyusui & 2 & 5,9 \\
\hline MP-ASI dini & 1 & 2,9 \\
\hline \multicolumn{3}{|l|}{$\begin{array}{l}\text { Apakah ada upaya mengatasi masalah } \\
\text { menyusui ketika masa anak ASi Ekslusif } \\
(n=18)\end{array}$} \\
\hline Ya & 8 & 44 \\
\hline Tidak & 10 & 56 \\
\hline $\begin{array}{l}\text { Melanjutkan pemberian ASI }(n=34) \\
\text { setelah } 6 \text { bulan }\end{array}$ & & \\
\hline Ya & 15 & 44,1 \\
\hline Tidak & 19 & 55,9 \\
\hline \multicolumn{3}{|l|}{ Masalah Selama Menyusui ( $(n=34)$} \\
\hline Asi sedikit & 6 & 17,6 \\
\hline Putting terbenam & 2 & 5,9 \\
\hline Putting retak & 5 & 14,7 \\
\hline Payudara Bengkak & 4 & 11,8 \\
\hline Mastitis & 2 & 5,9 \\
\hline Putting retak dan payudara bengkak & 2 & 5,9 \\
\hline Asi terlambat keluar setelah melahirkan & 3 & 8,8 \\
\hline Bayi menolak menyusui & 2 & 5,9 \\
\hline Tidak ada masalah & 8 & 23,5 \\
\hline \multicolumn{3}{|l|}{$\begin{array}{l}\text { Tempat konsultasi kesulitan menyusui } \\
(\mathbf{n}=34)\end{array}$} \\
\hline Petugas Kesehatan (Dokter/Bidan/TPG) & 18 & 52,9 \\
\hline Kader Posyandu & 3 & 8,8 \\
\hline Orang Tua & 2 & 5,9 \\
\hline Suami & 1 & 2,9 \\
\hline Teman & 1 & 2,9 \\
\hline Tidak ada & 9 & 26,5 \\
\hline \multicolumn{3}{|l|}{ Dukungan Menyusui (n=34) } \\
\hline Suami & 5 & 14,7 \\
\hline Suami dan Orang Tua & 6 & 17,6 \\
\hline Suami dan Keluarga & 6 & 17,6 \\
\hline Suami dan Petugas Kesehatan & 6 & 17,6 \\
\hline Orang Tua & 1 & 2,9 \\
\hline Keluarga & 4 & 11.8 \\
\hline Petugas Kesehatan & 3 & 8,8 \\
\hline Tidak ada & 3 & 8,8 \\
\hline \multicolumn{3}{|l|}{ Pemberian botol dot $(n=34)$} \\
\hline Ya & 25 & 73,5 \\
\hline Tidak & 9 & 26,5 \\
\hline \multicolumn{3}{|l|}{$\begin{array}{l}\text { Usia Anak di perkenalkan botol susu } \\
(\mathrm{n}=25)\end{array}$} \\
\hline$<6$ bulan & 19 & 76 \\
\hline-12 bulan & 3 & 12 \\
\hline$>12$ bulan & 3 & 12 \\
\hline
\end{tabular}

\section{PEMBAHASAN}

Berat badan kurang (underweight) atau sangat kurang (severely underweight) merupakan indikator yang dapat digunakan untuk melihat kemungkinan anak mengalami masalah pertumbuhan ${ }^{10}$. Walaupun masih harus dikonfirmasi dengan indeks antropometri yang lain karena hanya indikator status gizi akut, tapi anak dengan berat badan kurang jika tidak segera di tangani dan terjadi dalam waktu yang lama pada anak tersebut maka bisa anak tersebut menjadi stunting di waktu yang akan datang. Anak yang memiliki berat badan kurang baik karena asupan makanan atau penyakit infeksi yang di alami sejak lahir sampai anak balita di pastikan akan mempunyai tinggi badan yang pendek atau Stunting ${ }^{10}$. Pertumbuhan yang lambat akibat masalah pertumbuhan yang tidak segera di tangani pada anak waktu balita juga akan mempengaruhi kecerdasan otak anak setelah menginjak waktu dewasa dan mempengaruhi prestasi belajar dan olahraganya.

1000 Hari Pertama Kehidupan merupakan periode emas masa tumbuh kembang anak. WHO merekomendasikan 4 pemebriam makan pada anak yaitu memerikan IMD, menyusui ASI ekslusif, Mengenalkan MP-ASI setalah 6 bulan dan melanjutkan pemberian ASI sampai 2 tahun $^{11}$.

\section{Karakteristik Ibu dan Anak Balita Gizi Kurang.}

Baduta dengan berat badan kurang yang ada diwilayah kerja puskesmas mamboro di asuh oleh ibu yang umurnya dalam rentang usia 20 tahun sampai dengan 43 tahun. Rekomendasi umur wanita untuk hamil adalah dalam rentang 20 sampai dengan 35 tahun, karena proses hamil membutuhkan kesiapan emosi, psikologis, sosial dan ekonomi yang baik. Sama halnya dengan hamil, menyusui merupakan fitrah perempuan yang harus perankan oleh wanita setelah melewati proses kehamilan dalam keadaan yang penuh dramatis dan perlu kesiapan fisik, mental, emosi, psikologis, social dan ekonomi dalam menjalaninya. ${ }^{12}$

Pendidikan ibu yang memiliki anak baduta dengan kejadian berat badan kurang dipenelitian ini, di dominasi dengan lulusan SMA/sederajat. Banyak perempuan di luar sana yang tidak mampu secara ekonomi atau atau tidak tertarik lagi melanjutkan pendidikannya kejenjang yang lebih tinggi setelah mereka menyelesaikan pendidkan sekolah dasar 9 tahun. Mereka lebih memilih untuk berkiprah sebagai ibu rumah tangga dan berperan lebih di rumah ketimbang bekerja di luar ${ }^{13}$. Akhir-akhir ini bisa kita amati bahwa formasi lowongan 
pekerjaan di dominasi oleh penerimaan tenaga kerja yang memiliki latar belakang pendidikan diploma/sarjana atau yang lebih tinggi, maka menjadi sulit untuk perempuan yang mempunyai Pendidikan minimal SMA bersaing di dunia kerja. Pekerjaan ibu dalam penelitian ini adalah didominasi sebagai URT. Ibu yang tidak bekerja di luar dan berperan penuh dikeluarga mempunyai kesempatan menemani bayinya dirumah dibandingkan dengan ibu yang bekerja. ${ }^{1415}$

Status Paritas yang dihubungakan dengan pengalaman menyusui sebelumnya akan mempengaruhi pengalaman ibu untuk menyusui pada kelahiran-kelahiran selanjutnya. Asumsinya ibu sudah memiliki pengalaman pada laktasi pertama sehingga berpengalaman pada laktasi kedua dan seterusnya ${ }^{16}$. Ibu dengan paritas multipara mempunyai Teknik menyusui yang lebih baik. Teknik meyusui yang di maksud adalah perlekatan dan posisi yang baik serta sudah mempunyai keterampilan cara mangatasi jika terjadi masalah dalam menyusui yaitu putting lecet dan payudara bengkak ${ }^{1718}$.

Jumlah anak dalam keluarga berkaitan dengan beban kerja ibu yang berperan sebagai pengurus rumah tangga, Keluarga dengan jumlah anak banyak dan jarak kelahiran yang kurang dari 2 tahun akan mempengaruhi kesiapan mental ibu untuk mengurus keluarga termasuk mempengaruhi emosionalnya ${ }^{12}$,

Berat badan lahir rendah dan Panjang badan lahir pendek menjadi factor resiko kejadian stunting pada anak jika tidak diintervensi dengan baik ${ }^{1920}$.

\section{Praktik Menyusui pada Anak Gizi Kurang.}

Meningkatkan pemberian ASI terutama pemberian ASI eksklusif dapat membantu mempercepat tercapainya tujuan gizi secara global yaitu stunting dan masalah berat badan kurang pada anak. tingkat menyusui yang tidak memadai disebabkan oleh faktor sosial dan budaya, sistem kesehatan dan bisnis serta rendahnya pengetahuan tentang menyusui ${ }^{21}$.

Praktik menyusui tidak akan memadai jika masih ada keyakinan ibu/pengasuh dan masyarakat yang mendukung pemberian Makanan Pendamping ASI di bawah usiaa anak 6 bulan. Pemberian Makanan Pendamping ASI (MP-ASI) yang terlalu cepat dari usia yang disarankan muncul karena ada anggapan bahwa menyusui saja tidak cukup. Pada penelitian ini masih ada ibu yang memberikan makanan padat saat usia anak 3 bulan dengan alasan ibu tersebut merasa bahwa ASI-nya saja tidak cukup memenuhi kebutuhan bayi ${ }^{22}$.

Petugas Kesehatan merupakan bagian dari faktor yang berperan penting terkait dengan peningkatan praktik menyusui pada ibu. Diperlukan adanya dukungan keterampilan yang memadai (di fasilitas kesehatan dan di masyarakat). Hasil penelitian ini menggambarkan bahwa sebesar 76,4 \% ibu masih mengalami masalah terkait dengan menyusui. Dua dari delapan orang ibu yang mengatakan tidak mengalami masalah menyusui di karenakan ibu tersebut tidak memberikan ASI bayinya sejak bayinya berusia 0 bulan. Jika masalah menyusui yang muncul selama menyusui tidak di tangani dengan tepat maka bisa menjadi faktor penyebab ibu kesulitan untuk melanjutkan praktik menyusui pada ananknya serta berisiko terjadinya depresi postpartum ${ }^{23}$.

Faktor selanjutnya yang mempengaruhi keberhasilan praktik menyusui adalah kurangnya pengetahuan tentang bahaya menyusui yang tidak memadai dan teknik menyusui yang tepat di antara wanita, pasangan, keluarga, penyedia layanan kesehatan dan pembuat kebijakan ${ }^{21}$. Hasil penelitian menunjukkan bahwa sebesar 91,1\% ibu menyusui mendapatkan dukungan dari suami dan lingkungan sekitarnya dalam praktik menyusui.

Memperkenalkan botol susu pada bayi bisa mengakibatkan bayi mengalami kondisi bingung puting, hal ini disebabkan bayi kesulitan mengisap air susu ibu (ASI) langsung dari payudara karena bisa saja sudah terbiasa minum dari botol susu. Ketika sudah diperkenalkan dengan botol susu, bayi menjadi tidak harus bersusah payah mengeluarkan cairan dalam botol susu tersebut ini berbeda jika bayi disusui langsung, bayi perlu bekerja keras menggerakkan 40 otot wajahnya untuk mengelurkan ASI dari payudara ibu. Sebuah penelitian melaporkan bahwa memperkenalkan atau menggunakan botol susu pada bayi mempunyai pengaruh terhadap efektifitas kemampuan bayi mengisap putting payudara ibu saat menyusui, respon bayi terhadap payudara dan posisi bayi saat menyusui ${ }^{2425}$. Hasil penelitian ini menunjukkan bahwa sebesar 73,5\% diperkenalkan botol susu dan $76 \%$ usia yang di perkenalkan adalah usia pemberian ASI ekkslusif. Hampir Sebagian besar memperkenalkan botol susu pada anaknya dan paling banyak di perkenalkan di 
usia anak kurang dari 6 bulan. Memperkenalkan botol susu pada bayi terlalu dini akan mempengaruhi kemampuan bayi meyusui yang berdampak pada perlekatan yang kurang baik dan menyebabkan ketidak berhasilam pemberian ASI khususnya ASI Ekslusif.

\section{KESIMPULAN DAN SARAN}

Mengatasi berat badan kurang pada anak baduta di butuhkan praktik menyusui yang baik di masyarakat. Praktik menyusui pada baduta dengan berat badan kurang di Wilayah Kerja Puskesmas Mamboro masih banyak yang belum sesuai. Masih ada ibu yang tidak dilakukan IMD di tempat pelayanan Kesehatan, Masih ada bayi yang tidak diberikan ASI Eksklusif dan ibu yang mengalami masalah pada pemberian ASI Eksklusif ada yang tidak melakukan upaya dalam mengatasi masalah tersebut. Hampir semua ibu mengalami masalah menyusui baik yang karena kondisi fisik payudara dengan putting datar dan tenggelam maupun anggapan asinya sedikit keluar sehingga tidak cukup. Pemberian botol susu pada pada usia baduta banyak pada anak berusia di bawah 6 bulan.

Saran berdasarkan hasil penelitian adalah sebaiknya ada kegiatan pendampingan ibu hamil dan keluarga pendamping oleh petugas Kesehatan khususnya yang trimester ketiga, Pendampingan bukan hanya mengedukasi ibu hamil tapi juga memastikan keluarga yang mendampingi ibu hamil tersebut ikut andil mendukung bayi di berikan IMD sesaat setelah di lahirkan. Melakukan kegiatan peningkatan kemampuan petugas kesehatan sebagai konselor laktasi dan pelatihan yang terkait dengan upaya mengatasi masalah pada saat menyusui. Melibatkan kegiatan pemberdayaan masyrakat pendukung menyusui di masyarakat yang melibatkan multisector. Melakukan edukasi mengenai media pemberian cairan pada bayi.

\section{UCAPAN TERIMA KASIH}

Ucapan terima kasih di sampaikan kepada kepala puskesmas mamboro terutama tenaga pelaksana gizi dan kader posyandu yang ada di wilayah kerja puskesmas mamboro. Mahasiswa pengampuh mata kuliah konseling menyusui jurusan gizi poltekkes kemenkes palu dan direktur serta ketua jurusan gizi Poltekkes Kemenkes Palu.

\section{DAFTAR PUSTAKA}

1. Nasional RK, Thn ART. Launching Hasil Studi Status Gizi Indonesia (SSGI). 2021;114.

2. Kemenkes RI. Hasil Studi Status Gizi Indonesia (SSGI) Kabupaten/Kota Tahun 2021. 2021.

3. Izwardy D. Studi Status Gizi Balita Terintegrasi Susenas 2019. Balitbangkes Kemenkes RI. 2020.

4. Kementerian Kesehatan Republik Indonesia. Laporan Kinerja Kementrian Kesehatan Tahun 2020. Kementerian Kesehatan Republik Indonesia Tahun 2021. 2021. 1-224 p.

5. Kementrian Kesehatan. Situasi Stunting di Indonesia. Jendela data dan informasi kesehatan. 2018;208(5):1-34.

6. WHO. Global Strategy for Infant and Young Child Feeding. Fifthy-fourth world health assembly. 2003;(1):8.

7. Iswari L. Pengaruh covid19 terhadap aktivitas pertumbuhan ekonomi di indonesia. :13-20.

8. Sayuti RH, Hidayati SA. Dampak Pandemi Covid-19 Terhadap Ekonomi Masyarakat di Nusa Tenggara Barat. RESIPROKAL: Jurnal Riset Sosiologi Progresif Aktual. 2020;2(2):133-50.

9. World Health Organization, UNICEF. Infant and young child feeding counselling: an integrated course. Who. World Health Organization UNICEF; 2006. 1-265 p.

10. Permenkes R. Standart antropometri anak. 2 Indonesia; 2020.

11. World Health Organization. Complementary Feeding: Family foods for breastfed children. Departemen of Nutrition for Health and Development. 2000;1-56.

12. Prihandini SR, Pujiastuti W, Hastuti TP. Usia Reproduksi Tidak Sehat Dan Jarak Kehamilan Yang Terlalu Dekat Meningkatkan Kejadian Abortus Di Rumah Sakit Tentara Dokter Soedjono Magelang. Jurnal Kebidanan. 2016;5(10):47-57.

13. Khayati EZ. Pendidikan dan Independensi Perempuan. Musãwa Jurnal Studi Gender dan Islam. 2008;6(1):19.

14. Marwiyah N, Khaerawati T. Faktor-Faktor Yang Berhubungan Dengan Pemberian ASI Eksklusif Pada Ibu Bekerja di Kelurahan Cipare Kota Serang. Faletehan Health Journal. 2020;7(1):18-29.

15. Adhyanti, Kusumawati DE, Afifah R. Praktek Pemberian Asi Ekslusif Pada Ibu Pekerja Di Desa Batusuya Kabupaten Donggala. Svasta Harena : Jurnal Ilmu Gizi. 2021;1(2).

16. Aryotochter AAM. Praktik Pemberian Asi Eksklusif Pada Ibu Bekerja Di PT . APAC INTI CORPORA ( Kajian Teori Health Belief Model Dalam Manajemen Laktasi ) SKRIPSI. 
2016.

17. Pasiak SM, Pinontoan O, Rompas S. Status Paritas Dengan Teknik Menyusui Pada Ibu Post Partum. Jurnal Keperawatan. 2019;7(2).

18. Ansik KhoiriyahR, Prihatini. Hubungan antara paritas dengan ketrampilan menyusui yang benar pada ibu nifas. Jurnal Midpro. 2021;2(1997):2013-5.

19. Amaliah N, Sari K, Suryaputri IY. Panjang Badan Lahir Pendek Sebagai Salah Satu Faktor Determinan Keterlambatan Tumbuh Kembang Anak Usia 6-23 Bulan Di Kelurahan Jaticempaka, Kecamatan Pondok Gede, Kota Bekasi. Jurnal Ekologi Kesehatan. 2016;15(1):3-9.

20. Sutrio. Lupiana M. Berat Badan dan Panjang Badan Lahir Meningkatkan Kejadian Stunting. Jurnal Ilmiah Kesehatan. 2021;14(1):8.

21. WHO/UNICEF. Global Nutrion Target 2025.Breastfeeding Policy Brief.WHO/MNH/NHD 14.7. WHO/UNICEF; 2012. 8 p.

22. Nisma N, Juliana D, Lestari A. Faktor Yang Mempengaruhi Pemberian MP-ASI Dini Di Wilayah Kerja Puskesmas Siantan Tengah. Khatulistiwa Nursing Journal. 2021;3(1):2837.

23. Sukma F, Revinel R. Masalah Menyusui sebagai Determinan Terjadinya Risiko Depresi Postpartum pada Ibu Nifas Normal. Jurnal Bidan Cerdas. 2020;2(3):121-31.

24. Zimmerman E. Pacifier and bottle nipples: the targets for poor breastfeeding outcomes. Jornal de Pediatria. 2018;94(6):571-3.

25. Nasrul N, Hafid F, Ramadhan K, Suza DE, Efendi F. Factors associated with bottle feeding in children aged 0-23 months in Indonesia. Children and Youth Services Review. 2020;116(April):0-4. 